\title{
Multiple Endocrine Neoplasia Type I: A Patient Presenting as a Phenocopy
}

\author{
Samuel E Long1, Samuel Hyde ${ }^{2}$ and Nancy Perrier ${ }^{3 *}$ \\ ${ }^{1}$ Department of Surgery, University of Texas, USA \\ ${ }^{2}$ Department of Clinical Cancer Genetics, Anderson Cancer Center, USA \\ ${ }^{3}$ Department of Surgical Oncology, Anderson Cancer Center, USA
}

Submission: June 21, 2017; Published: July 17, 2017

*Corresponding author: Nancy Perrier, MD, Department of Surgical Oncology, Anderson Cancer Center 1515 Holcombe Blvd \#853, Houston, TX 77030, USA, Email: NPerrier@mdanderson.org

\section{Background}

Multiple Endocrine Neoplasia Type I (MEN1) is a hereditary disease characterized by the presence of multiple tumors, most commonly in the endocrine pancreas, parathyroid, and pituitary glands [1]. It is an autosomal dominant disease caused by germline mutations in the MEN1 tumor suppressor gene [2]. In contrast to sporadic primary hyperparathyroidism (PHPT), which is typically associated with a single adenomatous gland, patients with MEN1 more often present with multi gland disease and/or diffuse hyperplasia [3]. We report a case of a male patient with early-onset PHPT and a family history of MEN1 who was identified to be a phenocopy.

\section{Case Report}

A 37 year-old male with an extensive family history of MEN1 presented to our outpatient surgical endocrinology clinic with a recent diagnosis of nephrolithiasis. He underwent biochemical evaluation at that time which was consistent with PHPT. Sestamibi parathyroid SPECT/CT identified a $0.9 \mathrm{~cm}$ lesion with concentrated uptake inferior to the pole of the right thyroid lobe, suggestive of single gland disease. Given his family history, targeted MEN1 genetic testing for a previously identified familial mutation was performed as was biochemical screening for concurrent pancreatic and/or pituitary disease. Despite localization of a single lesion, the suspicion for MEN1 in this patient was extremely high and he was scheduled for a subtotal parathyroidectomy and prophylactic cervical thymectomy, as is the recommended surgical management of MEN1-associated PHPT [4].

Our patient's mother, brother, and a niece were all previously diagnosed with MEN1. His mother was diagnosed clinically, with a history of multigland PHPT and a prolactinoma. Her son, our patient's brother and the proband of the family, was also identified to have MEN1 based on the presence of PHPT, a pituitary tumor, and pancreatic neuroendocrine tumor. He had undergone genetic testing which identified a pathogenic MEN1 mutation, p. E563X (c.1687G>T). This variant had been reported previously in the literature, and is caused by a nonsense mutation in exon 10 resulting in a premature stop codon and is predicted to cause loss of normal protein expression through protein truncation [5]. Our patient's mother subsequently underwent targeted testing for this variant and, as expected, tested positive. Additionally the proband's daughter also tested positive for the familial mutation.

Targeted MEN1 genetic testing for the E563X pathogenic variant in our patient was negative. The genetic testing laboratory confirmed that the correct sample and correct primers were used to evaluate for the presence of this variant. Given these unexpected results, a new peripheral blood sample was obtained from our patient and comprehensive MEN1 testing (sequencing of all coding regions and deletion/duplications analyses) identified no apparent mutations on either copy of our patient's MEN1 genes. As a result, the patient's case was reviewed and the decision was made to proceed with a minimally invasive parathyroidectomy only. Intraoperatively, there was an appropriate drop in his parathyroid hormone level, from $151.6 \mathrm{pg} / \mathrm{mL}$ to $34.1 \mathrm{pg} / \mathrm{mL}$ at 5 minutes (78\% drop) and $27.0 \mathrm{pg} /$ $\mathrm{mL}$ at 10 minutes ( $82 \%$ drop). Consequently, we were able to avoid unnecessary exploration of the remaining glands.

\section{Conclusion}

Despite the high suspicion that our patient had MEN1, our patient with PHPT was ultimately a phenocopy of his mother and brother, meaning that he exhibited an MEN-1 phenotype that did 
not result from the familial MEN1 genotype. Phenocopies have been described in the MEN1 literature and have been reported to occur in as many as 5\% of MEN1 families [6]. While phenotypic expression is variable, the majority of MEN1 phenocopy patients do present with primary hyperparathyroidism from single gland disease [7]. Our patient highlights the importance of confirmatory genetic testing in patients with suspected MEN1 and the need to obtain these results prior to surgery. Our patient was able to undergo a minimally invasive, targeted parathyroidectomy as a result of his genetic testing and was spared a subtotal parathyroidectomy and cervical thymectomy, which would have increased his surgical risk and potentially, his hospital length of stay. Additionally, his negative genetic test result indicates that he will not need surveillance (biochemical or imaging studies) for other MEN1-associated tumors and that any future children are not as risk for MEN1 despite his diagnosis of PHPT. Moving forward, we plan to evaluate for any evidence of recurrence and to confirm that he does not develop multi-gland disease (Figure 1).

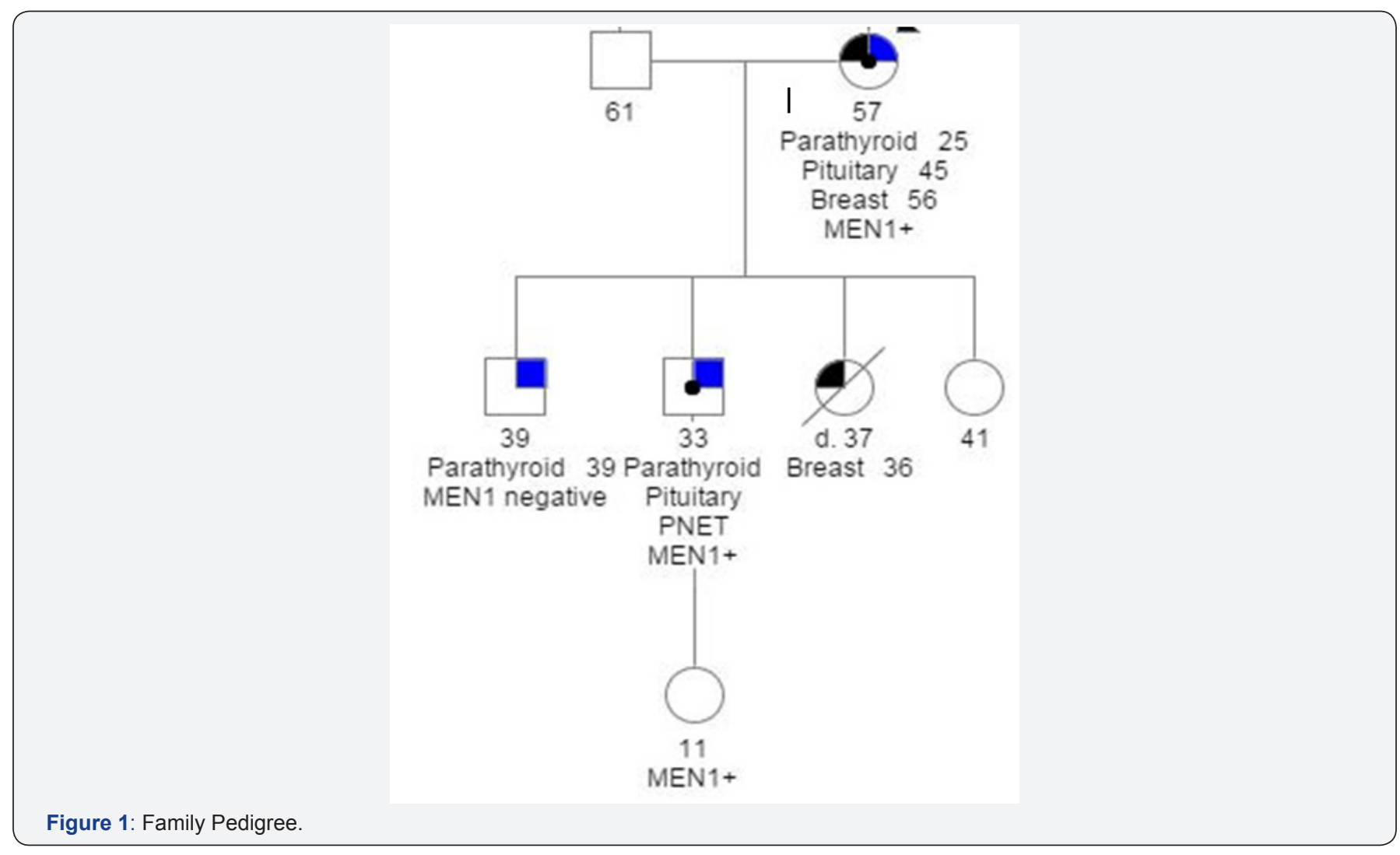

\section{References}

1. Thakker RV, Newey PJ, Walls GV, Bilezikian J, Dralle H, et al. (2012) Clinical practice guidelines for multiple endocrine neoplasia Type I (MEN1). J Clin Endocrinol Metab 97(9): 2990-3011.

2. Larsson C, Calendar A, Grimmond S, Giraud S, Hayward NK, et al. (1995) Molecular tools for presymptomatic testing in multiple endocrine neoplasia type 1. J Intern Med 238(3): 239-244.

3. Eller-Vainicher C, Chiodine I, Battista C, Viti R, Mascia ML, et al. (2009) Sporadic and MEN1-related primary hyperparathyroidism: differences in clinical expression and severity. J Bone Miner Res 24(8):1404-1410.

4. Carling T, Udelsman R (2005) Parathyroid surgery in familial hyperparathyroid disorders. J Intern Med 257(1): 27-37.

5. Klein RD, Salih S, Bessoni J, Bale AE (2005) Clinical testing for multiple endocrine neoplasia type 1 in a DNA diagnostic laboratory. Genet Med $7(2): 131-138$.

6. Turner JJ, Christie PT, Pearce SH, Turnpenny PD, Thakker RV (2010) Diagnostic challenges due to phenocopies: lessons from Multiple Endocrine Neoplasia type1 (MEN1). Hum Mutat 31(1): E1089-E1101.

7. Sakurai A, Kata M, Yumita W, Minemura K, Hashizume K (2004) Clinical and genetic features of patients with multiple endocrine tumors who have neither family history nor MEN1 germline mutations. Endocrine 23(1): 45-49. 
This work is licensed under Creative Commons Attribution 4.0 Licens

DOI:10.19080/JETR.2017.02.555590

\section{Your next submission with Juniper Publishers will reach you the below assets}

- Quality Editorial service

- Swift Peer Review

- Reprints availability

- E-prints Service

- Manuscript Podcast for convenient understanding

- Global attainment for your research

- Manuscript accessibility in different formats

( Pdf, E-pub, Full Text, Audio)

- Unceasing customer service

Track the below URL for one-step submission https://juniperpublishers.com/online-submission.php 